\title{
Evaluation of the semen quality of patients attended in a clinical analyzes in the Cascavel municipality, Brazil
}

\author{
Danieli Webber dos Reis' ${ }^{1}$, Claudinei Mesquita da Silva ${ }^{1,2}$, Heloise Skiavine Madeira', Veridiana Lenartovicz Boeira ${ }^{3}$ \\ Denise Michele Indras ${ }^{4}$, Jorge Juarez Vieira Teixeira ${ }^{5}$, Leyde Daiane de Peder ${ }^{1,5^{*}}$ \\ 'Laboratório de Análises Clínicas, Centro Universitário da Fundação Assis Gurgacz, Cascavel, PR, Brasil \\ 2Programa de Pós-Graduação em Ciências da Saúde, Universidade Estadual de Maringá (UEM), Maringá, PR, Brasil \\ ${ }^{3}$ Centro de Ciências Médicas e Farmacêuticas, Universidade Estadual do Oeste do Paraná (UNIOESTE), Cascavel, PR, Brasil \\ ${ }^{4}$ Laboratório Municipal de Cascavel, Cascavel, Paraná, Brasil \\ ${ }^{5}$ Programa de Pós-Graduação em Biociências e Fisiopatologia, Universidade Estadual de Maringá (UEM), Maringá, PR, Brasil
}

\begin{abstract}
Objectives: The objective of this study was to investigate the prevalence of altered spermograms of individuals living in a municipality in the west of Paraná and attended at a private laboratory for clinical analysis, as well as the main alterations found in this study. Methods: We analyzed electronic reports of patients undergoing sperm examination in a private laboratory located in the municipality of Cascavel, Paraná, from January 2014 to December 2016. Results: It was verified that of 888 tests analyzed, only $1 \%$ presented all parameters analyzed within normality, while $99 \%$ of the cases presented some type of alteration. There was a change in the following parameters with statistical significance between the number of reports analyzed: time of liquefaction, sperm concentration, head anomalies, tail abnormalities, number of spermatocytes and spermatids $(p<0.0001)$, viscosity $(p=0.1098)$, live forms $(p=0.0524)$, progressive motility $(p=0.0010)$ and total motility $(p=0.0013)$. Conclusions: There was a high prevalence of altered spermograms and a great number of alterations were observed, which requires the need for complementary tests to determine the causes of these alterations.
\end{abstract}

Keywords: semen; semen analysis; infertility.

\section{Introduction}

According to the American Society of Reproductive Medicine, infertility is the disease of the reproductive system, characterized by the inability of a couple to bear children after one year of sexual intercourse without the use of contraceptive methods. Reproductive inability can be related to innumerable causes, such as anatomical, hormonal, genetic, biochemical and immunological changes, arising from infections, exposure to environmental factors or even the individual's lifestyle. ${ }^{2}$

Humans have moderately low fertility. Only $50 \%$ of couples with reproductive capacity will have children in three months, $75 \%$ in six months, $90 \%$ in one year and $95 \%$ in two years. ${ }^{3-5}$ Male infertility affects on average $10 \%$ of men of age however, most of these cases have specific treatment. ${ }^{6}$ This treatment, in turn, should be guided by professionals who can handle the needs of each patient. ${ }^{7}$ The average is that 1 in 15 men have fertility problems. ${ }^{8}$ According to Dohle et al. ${ }^{9}$, research by the World Health Organization (WHO) shows that in every 4 couples seeking treatment for infertility, in at least one of them, both sexes have abnormalities. The inability to generate children reaches men and women around the world. In 2010, approximately $48.5 \%$ of couples had infertility problems. In addition, methodological differences and diagnostic errors greatly increase these numbers. ${ }^{7}$

Financial support: None.

Conflicts of interest: The authors declare no conflicts of interest.

Submitted: December 19, 2017.

Accepted: August 19, 2019.

The study was carried out at University Center of Assis Gurgacz Foundation, Cascavel, PR, Brazil.

Copyright Reis et al. This is an Open Access article distributed under the terms of the Creative Commons Attribution License, which permits unrestricted use, distribution, and reproduction in any medium, provided the original work is properly cited. 
According to the epidemiological studies of Boivin et al. ${ }^{4}$, in developed countries the incidence of infertility varies from $3.5 \%$ to $16.7 \%$ after one year of sexual intercourse without contraceptive methods. In the least developed countries, there was a change from 6.9\% to 9.3\%, with a global average of 9\%. In Brazil, infertility affects on average 18\% of couples, and the most common causes are episodes of pelvic infectious processes contracted by sexual intercourse and postpartum, or post-abortion due to precarious situations. ${ }^{10}$ Thus, the present study aims to determine the prevalence and main changes observed in the semen of individuals living in the Cascavel municipality, in the west of Paraná, Brazil, from January 2014 to December 2016.

\section{Methods}

This is a cross-sectional and descriptive study, in which data were collected from sperm-type electronic reports in the SIAC system (Sistema Integrado de Análises Clínicas), issued by a private laboratory located in the municipality of Cascavel,

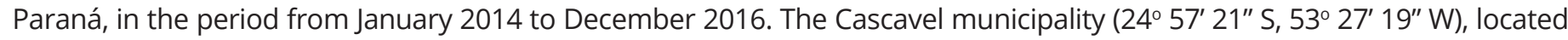
in the west region of Paraná, has a land area of 2,100,831 $\mathrm{m}^{2}$ and a population of 312,778 inhabitants, as estimated by the Instituto Brasileiro de Geografia e Estatística (IBGE).

All the reports of patients residing in Cascavel, who performed seminal analysis during the period determined in the laboratory in question, were included in the study, and reports were excluded from patients not resident in Cascavel, or who performed seminal analysis outside the research period.

According to the laboratory that carried out the analyzes, patients were instructed to maintain a abstinence time of two to five days and to perform semen collection by masturbation and to deposit in sterile bottles. After collection, the seminal fluid was maintained at a temperature of $37^{\circ} \mathrm{C}$ until complete liquefaction and then macroscopic and microscopic examinations were performed. The methodology used for the sperm analysis was according to the World Health Organization.

The following variables were collected from the analyzed reports: service order number, initials of each patient, date of examination, liquefaction time, volume, appearance, color, viscosity, pH, sperm concentration, number of live forms, motility, morphology, type and percentage of anomalies (head, middle part and tail), number of leukocytes and red blood cells.

The data collected were stored in Microsoft Excel ${ }^{\circledR}$ and for analysis and study on the association between variables, the Chi-square test (test $x^{2}$ ) was used at a significance level of 5.0\%, with results considered statistically significant for $p \leq 0.05$. Statistical analysis was performed using Bioestat ${ }^{\circledR}$ software, version 4.0. The work was approved by the Ethics Committee in Human Research beings of the University Center of the Assis Gurgacz Foundation, under opinion 857.540/2014.

\section{Results}

A total of 888 reports, of which $9(1 \%)$, were within the normal parameters considered by the Laboratory Manual for the Examination and Processing of Human Sperm, ${ }^{11}$ the remaining 879 (99\%) presented results with some type of changes in the parameters evaluated. The volume, color, viscosity, $\mathrm{pH}$, sperm concentration, number of live forms, motility, morphology, type and percentage of anomalies (head, middle part and tail), number of leucocytes and red blood cells. Regarding macroscopic examination, the majority of the individuals presented parameters for seminal analysis outside the values established by the World Health Organization. Viscosity changes were observed, with 39.3\% (348) of the samples showing increased viscosity and 37.2\% (330) decreased. Regarding the parameters volume, appearance and coloration, $15.7 \%$ (140) presented volume below that established, 90\% (798) homogeneous appearance and $97.4 \%$ (865) pearl white coloration. In $80.6 \%$ (716) of the cases, the liquefaction time remained less than or equal to 60 minutes and in $89.0 \%$ (825) the $\mathrm{pH}$ was greater than or equal to 7.2 (Table 1).

In the microscopic analysis, $72.7 \%$ (587) of the reports had sperm concentrations within the established ( $\geq 15 \mathrm{million} / \mathrm{ml}$ ) and $39.8 \%$ (305) showed vitality below the indicated values. In the analyzed cases, up to 1000 leukocytes $/ \mathrm{mm}^{3}$ and $98.4 \%$ (860) up to 1000 red cells $/ \mathrm{mm}^{3}$ were found in $98 \%$ (857), which is within normal limits (Table 2).

Regarding progressive motility, 67\% (519) were below recommended and total motility, 66.6\% (516) of the cases presented values below that established. The morphology was found to be within the standards in $99.9 \%(745)$ of the reports, and spermatocytes and spermatids were also within the limits in 73.3\% (561) of the cases (Table 3). The data in Table 4 shows the types and percentage of the anomalies found. Among the head anomalies, microcephalic ones were the ones that presented the most changes (86.2\%/658 cases). Two types of intermediate part anomalies were observed, the thickened being verified in a greater percentage of spermatozoa $(95.4 \% / 725)$. For tail abnormalities, rolled up was seen in most cases (96.2\%/732). 
Table 1. Macroscopic characteristics of the semen of individuals who performed sperm in a clinical analysis laboratory in Cascavel, Paraná, Brazil, 2014 - 2016

\begin{tabular}{|c|c|c|c|c|}
\hline \multirow{2}{*}{ Variables Analyzed } & \multirow{2}{*}{ Reference values } & \multicolumn{2}{|c|}{ Reports } & \multirow{2}{*}{ p-value } \\
\hline & & $\mathrm{n}$ & $\%$ & \\
\hline \multirow{2}{*}{ Volume } & $\geq 1.5 \mathrm{ml}$ & 748 & 84.2 & \multirow{2}{*}{$<0.0001$} \\
\hline & $<1.5 \mathrm{ml}$ & 140 & 15.7 & \\
\hline \multirow{2}{*}{ Aspect } & Homogeneous & 798 & 90.0 & \multirow{2}{*}{$<0.0001$} \\
\hline & Heterogeneous & 89 & 10.0 & \\
\hline \multirow{4}{*}{ Color } & Pearl White & 865 & 97.4 & \multirow{4}{*}{$<0.0001$} \\
\hline & Yellow & 16 & 1.8 & \\
\hline & Reddish & 3 & 0.3 & \\
\hline & Brownish & 4 & 0.4 & \\
\hline \multirow{2}{*}{ Liquefaction time } & Until $60 \mathrm{~min}$ & 716 & 80.6 & \multirow{2}{*}{$<0.0001$} \\
\hline & $>60 \min$ & 172 & 19.4 & \\
\hline \multirow{3}{*}{ Viscosity } & Normal & 208 & 23.5 & \multirow{3}{*}{0.098} \\
\hline & Increased & 348 & 39.3 & \\
\hline & Decreased & 330 & 37.2 & \\
\hline \multirow{3}{*}{$\mathrm{pH}$} & $\leq 7.0$ & 36 & 4.1 & \multirow{3}{*}{$<0.0001$} \\
\hline & $\geq 7.2$ & 788 & 89.0 & \\
\hline & $>8.2$ & 61 & 6.9 & \\
\hline
\end{tabular}

Table 2. Spermatozoa number, live forms, leukocytes and erythrocytes in individuals who performed sperm in a private laboratory in Cascavel, Paraná, 2014 - 2016

\begin{tabular}{lcccc} 
Variables Analyzed & Reference value & $\begin{array}{c}\text { Reports within } \\
\text { normality }\end{array}$ & $\begin{array}{c}\text { Reports out of } \\
\text { normality }\end{array}$ & n (\%) \\
\cline { 2 - 3 } Sperm concentration & $\geq 15 \mathrm{millions} / \mathrm{mL}$ & $587(72.7)$ & $220(27.3)$ & $305(39.8)$ \\
Living Forms (Vitality) & $\geq 58 \%$ & $461(60.2)$ & $18(2.0)$ & $<0.0001$ \\
Leukocytes/ml & Until $1000 / \mathrm{mm}^{3}$ & $857(98.0)$ & $14(1.6)$ & $<0.0001$
\end{tabular}

Table 3. Progressive and total motility, normal spermatozoa, spermatocytes and spermatids in individuals who performed sperm in a private laboratory in Cascavel, PR, 2014 - 2016

\begin{tabular}{lccc}
\multicolumn{1}{c}{ Variables Analyzed } & Reference value & $\begin{array}{c}\text { Reports within } \\
\text { normality }\end{array}$ & $\begin{array}{c}\text { Reports out of } \\
\text { normality }\end{array}$ \\
& & $\mathbf{n}(\%)$ & $\mathbf{n}(\%)$ \\
P-value
\end{tabular}


Table 4. Anomalies of head, intermediate piece and tail in the reports analyzed in individuals who performed sperm in a private laboratory in Cascavel, Paraná, 2014 - 2016

\section{Reports number with anomalies presence}

Anomalies

n

\section{Head anomalies}

Macrocephalic

658

Microcephalic

487

Fusiform

Bicephalic

Amorphous

Intermediate anomalies part

Angled

683

725

Thickened

\section{Tail anomalies}

Short

559

Curled up

732

Double

316
$\%$

P-value

80.9

86.2

64.5

$<0.0001$

37.7

39.2

89.9

0.7465

95.3

73.6

96.2

41.5

\section{Discussion}

Although age was not described in the reports, it is one of the important factors when talking about male infertility. Studies confirm that semen quality decreases after 40 years, leading to changes in ejaculate such as sperm movement, morphology, and decreased sperm concentration. ${ }^{12}$ Regarding the microscopic examination, some parameters analyzed differed from those indicated by the World Health Organization. Health. In cases of motility, both progressive (67\%) and total (66.6\%) presented values below that specified. In a study reviewing WHO seminal parameters, they found that motility and concentration are the most correct factors to indicate fertilization capacity. ${ }^{13}$ One study considered sperm motility to be the most important when compared to the other seminal parameters. When motility values are lower than those established, there may be a great difficulty in generating children. ${ }^{14}$ In relation to sperm concentration, approximately $27.3 \%$ of the cases presented values below that stipulated. The reasons for sperm decline may be due to decreased sexual abstinence, or due to genetic disorders or infections. ${ }^{15-17}$

Among the agents that motivate changes in the quality of ejaculate are alcohol and tobacco that reduce sperm concentration and motility. ${ }^{18}$ This study showed that in $39.8 \%$ of the cases the vitality was below $58 \%$, which is considered reference value. A study carried out to evaluate the seminal parameters of 998 men, aged 20 to 60 years, observed that age is negatively associated with vitality, progressive motility and percentage of normal spermatozoa. ${ }^{19}$ Several studies have found a negative relationship between obesity and seminal parameters, verifying a reduction in vitality, sperm concentration, morphology, motility and sperm DNA integrity. ${ }^{20}$

The least divergent of the patterns was the morphology (Kruger morphology), since normal values were verified in 99.9\% of the cases. Some studies have investigated the relationship between semen morphology and age, and most of these studies show a reduction in the percentage of normal spermatozoa. ${ }^{21-23}$

When head and tail abnormalities were analyzed, statistically significant results $(p<0.0001)$ were observed, but when the anomaly of the intermediate part was analyzed, a significant result was not observed. In the studies of Schwartz et al. ${ }^{24}$, there was a small but significant decrease in morphological quality with advancing age. They also highlight an increase in the percentage of spermatozoa with head anomalies (microcephalus) and tail anomalies.

In the present study it was observed that leukocytes in $98 \%$ of cases remained within normal limits and only $2 \%$ of the cases presented indices below that established. In the research by Lackner et al. ${ }^{25}$, the presence of pathogenic bacteria in asymptomatic men was observed in the absence of leukocytospermia. He also noted that low concentrations of leukocytes are detrimental to semen quality and fertility. In 39.3\% of cases, increased viscosity was observed. The increased viscosity influences the liquefaction, which may be due to a reduction in the activity of prostatic enzymes, ${ }^{26}$ in this way impairing semen quality. 
Another significant parameter was the volume, which in $84.2 \%$ was within normal, being only $15.7 \%$ below that established. When Brahem et al. ${ }^{27}$ analyzed the semen parameters of 140 fertile and infertile men aged 24 to 70 years, they found that both fertile and infertile men presented a reduction in volume $(0.4$ to $0.8 \mathrm{ml})$ in men with age greater than or equal to 50 years when confronted with men younger than 50 years. There is little information that does not link seminal volume to the age of man. 24,28-29 Some studies have observed a reduction in volume in young men, 21-35 years, and in older men (46-50 years), larger volumes are observed in men aged 26 to 45 years. ${ }^{21,24,28}$

Another parameter that presented significance was the liquefaction time, which should occur in up to 60 minutes to be considered complete. $19.4 \%$ of the cases presented incomplete liquefaction, since they liquefied after the 60 minutes. Incomplete liquefaction, after the set time of incubation, may indicate the lack of prostatic enzymes. ${ }^{30}$ In the present study, $4.07 \%$ of the reports had a pH equal to or lower than 7 . When it has a low concentration and a pH lower than 7 , it can mean an ejaculatory canal block or a bilateral congenital lack of the vas deferens. ${ }^{11,30}$

The coloration of a homogeneous and liquefied sample is considered white, gray or yellow. ${ }^{11}$ In the present study, it was observed that in $99.21 \%$ of the cases the color remained within normality. When talking about diagnosis of infertility, the sperm must be performed along with other tests to assist in the assessment. Several analyzes can be used to investigate a probable alteration, such as hormonal dosage, sperm analysis, karyotype analysis, histopathological examination of the testes ${ }^{21,31-33}$, antibody search, sperm fragmentation test and scrotal ultrasonography. ${ }^{34}$ These examinations, together with the spermogram, help in a more accurate diagnosis.

This study had some limitations. During the research, the absence of some information in the electronic reports was observed, minimizing the comparison of the information. In addition, our sample was a convenience sample, that is, the study was conducted only with those patients who sought care from a private laboratory, which may have been a source of bias, since these patients may present clinical, laboratory and epidemiological characteristics different from those seen in the public health system. In addition, we can observe differences when the sample is larger, that is, when patients from a larger number of laboratories are compared. Despite the inherent limitations of the manuscript, to a certain extent, it brings a positive contribution in relation to the epidemiological characteristics of the patients who presented spermogram alterations.

\section{Conclusion}

It was observed that 99\% (879) of the analyzed reports presented some type of alteration in relation to semen quality. The parameters that had a greater statistical significance in relation to normal and altered were volume, appearance, color, time of liquefaction, pH, sperm concentration, leukocytes, red blood cells, normal spermatozoa, head anomalies, tail anomalies, spermatocytes and spermatids. It is necessary to research and carry out complementary tests in order to guide patients about the aetiology of the problems observed for the use of measures that may contribute to their reduction and their consequences in relation to the possibility of these men having children.

\section{Acknowledgements}

The authors are grateful to the Laboratory Biovel de Análises e Pesquisas Clínicas for Clinical Analysis and Research, for all the data provided for this research.

\section{References}

1. Practice Committee of the American Society for Reproductive Medicine. Definitions of infertility and recurrent pregnancy loss. Fertil Steril. 2008;89(6):1603. http://dx.doi.org/10.1016/j.fertnstert.2008.03.002. PMid:18485348.

2. Cruz JC. Factores genéticos na infertilidade masculina [dissertação]. Viana do Castelo: Faculdade de Medicina, Universidade do Porto; 2010. 29 p.

3. Stirnemann JJ, Samson A, Bernard JP, Thalabard JC. Day-specific probabilities of conception in fertile cycles resulting in spontaneous pregnancies. Hum Reprod. 2013;28(4):1110-6. http://dx.doi.org/10.1093/humrep/des449. PMid:23340057.

4. Boivin J, Bunting L, Collins AJ, Nygren KG. International estimates of infertility prevalence and treatment seeking: potencial need and demand for infertility medical care. Hum Reprod. 2007;22(6):1506-12. http://dx.doi.org/10.1093/humrep/dem046 PMid:17376819.

5. Wilkes S, Chinn DJ, Murdoch A, Rubin G. Epidemiology and management of infertility: a population based study in UK primary care. Fam Pract. 2009;26(4):269-74. http://dx.doi.org/10.1093/fampra/cmp029. PMid:19502575.

6. Pasqualotto FF. Investigação e reprodução assistida no tratamento da infertilidade masculina. Rev Bras Ginecol Obstet. 2007;29(2):10312. http://dx.doi.org/10.1590/S0100-72032007000200008. 
7. Mascarenhas MN, Flaxman SR, Boerma T, Vanderpoel S, Stevens GA. National, regional, and global trends in infertility prevalence since 1990: a systematic analysis of 277 health surveys. PLoS Med. 2012;9(12):e1001356. http://dx.doi.org/10.1371/journal. pmed.1001356. PMid:23271957.

8. Lipshultz LI, Howards SS, Niederberger CS. Infertility in the male. Cambridge: Cambridge University Pres; 2009. http://dx.doi. org/10.1017/CBO9780511635656.

9. Dohle GR, Diemer T, Giwercm A, Jungwirth A, Kopa Z, Krausz C. Male infertility. Hakobyan: European Association of Urology; 2010.

10. Santos GC. Prevalência de microdeleções nas regiões AZFa, AZFb e AZFc do cromossomo Y em indivíduos com oligozoospermia ou azoospermia em Mato Grosso [dissertação]. Cuiabá: Universidade Federal do Mato Grosso; 2011.59 p.

11. World Health Organization. Laboratory manual for the examination and processing of human semen. Geneva: WHO; 2010.

12. Sloter E, Schmid TE, Marchetti F, Eskenazi B, Nath J, Wyrobek AJ. Quantitative effects of male age on sperm motion. Hum Reprod. 2006;21(11):2868-75. http://dx.doi.org/10.1093/humrep/del250. PMid:16793993.

13. Nallella KP, Sharma RK, Aziz N, Agarwal A. Significance of sperm characteristics in the evaluation of male infertility. Fertil Steril. 2006;85(3):629-34. http://dx.doi.org/10.1016/j.fertnstert.2005.08.024. PMid:16500330.

14. Elzanaty S, Malm J, Giwercman A. Duration of sexual abstinence: epididymal and accessory sex gland secretions and their relationship to sperm motility. Hum Reprod. 2005;20(1):221-5. http://dx.doi.org/10.1093/humrep/deh586. PMid:15550495.

15. Gonçalves J. Avaliação do casal infértil. Rev Port Clin Geral. 2005;21(5):493-503.

16. Barbosa FFS. Influência dos antioxidantes na qualidade do sêmen de homens em tratamento de fertilidade [dissertação]. Lisboa: Faculdade de Ciências, Universidade de Lisboa; 2009. 70 p.

17. Pasqualotto FF, Fonseca GP, Silva ML, Ferreira RV, Zago BE, Garbin C Jr, et al. Influência do período de abstinência sexual sobre as características seminais de homens inférteis. Rev Bras Ginecol Obstet. 2006;28(1):4449. http://dx.doi.org/10.1590/ S0100-72032006000100008.

18. Lima VM, Barbieri RL, Aquila AD, Myamora F, Duarte IS. Estudo histopatológico do efeito da nicotina nos testículos e epidídimos de ratos. Rev Bras Clin Med. 2012;10(4):322-8.

19. Zhu QX, Meads C, Lu ML, Wu JQ, Zhou WJ, Gao ES. Turning point of age for semen quality: a population-based study in Chinese men. Fertil Steril. 2011;96(3):572-6. http://dx.doi.org/10.1016/j.fertnstert.2011.06.058. PMid:21782163.

20. Du Plessis SS, Cabler S, Mcalister DA, Sabanegh E, Agarwal A. The effect of obesity on sperm disorders and male infertility. Nat Rev Urol. 2010;7(3):153-61. http://dx.doi.org/10.1038/nrurol.2010.6. PMid:20157305.

21. Hazout A, Dumont-Hassan M, Junca A-M, Bacrie PC, Tesarik J. High magnification ICSI overcomes paternal effect resistant to conventional ICSI. Reprod Biomed Online. 2006;12(1):19-25. http://dx.doi.org/10.1016/S1472-6483(10)60975-3. PMid:16454928.

22. Vagnini L, Baruffi RL, Mauri AL, Petersen CG, Massaro FC, Pontes A, et al. The effects of male age on sperm DNA damage in an infertile population. Reprod Biomed Online. 2007;15(5):514-9. http://dx.doi.org/10.1016/S1472-6483(10)60382-3. PMid:18028741.

23. Borini A, Tarozzi N, Bizzaro D, Bonu MA, Fava L, Flamigni C, et al. Sperm DNA Fragmentation: paternal effect on early postimplantation embryo development in ART. Hum Reprod. 2006;21(11):2876-81. http://dx.doi.org/10.1093/humrep/del251. PMid:16793992.

24. Kleinhaus K, Perrin M, Friedlander Y, Paltiel O, Malaspina D, Harlap S. Paternal age and spontaneous abortion. Obstet Gynecol. 2006;108(2):369-77. http://dx.doi.org/10.1097/01.AOG.0000224606.26514.3a. PMid:16880308.

25. Lackner J, Schatzl G, Horvath S, Kratzik C, Marberger M. Value of counting white blood cells (WCB) in semen samples to predit the presence of bacteria. Eur Urol. 2006;49(1):148-52, discussion 152-3. http://dx.doi.org/10.1016/j.eururo.2005.08.017. PMid:16314032.

26. Piva S. Espermograma - Análise e técnicas. 6. ed. Santos; 1985.

27. Brahem S, Mehdi M, Elghezal H, Saad A. The effects of male aging on semen quality, sperm DNA fragmentation and chromosomal abnormalities in an infertile population. J Assist Reprod Genet. 2011;28(5):425-32. http://dx.doi.org/10.1007/s10815-011-9537-5. PMid:21287403.

28. Berling S, Wolner-Hanssen P. No evidence of deteriorating semen quality among men in infertile relationships during the last decade: a study of males from Southern Sweden. Hum Reprod. 1997;12(5):1002-5. http://dx.doi.org/10.1093/humrep/12.5.1002. PMid:9194654.

29. Wyrobek AJ, Eskenazi B, Young S, Arnheim N, Tiemann-Boege I, Jabs EW, et al. Advancing age has differential effects on DNA damage, chromatin integrity, gene mutations, and aneuploidies in sperm. Proc Natl Acad Sci USA. 2006;103(25):9601-6. http:// dx.doi.org/10.1073/pnas.0506468103. PMid:16766665.

30. Jeyendran RS. Protocols for semen analysis in clinical diagnosis. 1st ed. New York: Parthenon Publishing; 2003.

31. Fisch H, Hyun G, Golden R, Hensle TW, Olsson CA, Liberson GL. The influence of paternal age on down syndrome. J Urol. 2003;169(6):2275-8. http://dx.doi.org/10.1097/01.ju.0000067958.36077.d8. PMid:12771769.

32. Garolla A, Fortini D, Menegazzo M, De Toni L, Nicoletti V, Moretti A, et al. High-power microscopy for selecting spermatozoa for ICSI by physiological status. Reprod Biomed Online. 2008;17(5):610-6. http://dx.doi.org/10.1016/S1472-6483(10)60307-0. PMid:18983744. 
33. Bartoov B, Berkovitz A, Eltes F, Kogosovsky A, Yagoda A, Lederman H, et al. Pregnancy rates are higher with intracytoplasmic morphologically selected sperm injection than with conventional intracytoplasmic injection. Fertil Steril. 2003;80(6):1413-9. http:// dx.doi.org/10.1016/j.fertnstert.2003.05.016. PMid:14667877.

34. American Society for Reproductive Medicine. Diagnostic evaluation of the infertile male: a committee opinion. Fertil Steril. 2015;103(3):18-25. http://dx.doi.org/10.1016/j.fertnstert.2014.12.103. PMid:25597249.

\section{*Correspondence}

Leyde Daiane de Peder

Programa de Pós-Graduação em Biociências e Fisiopatologia, Universidade Estadual de Maringá (UEM)

Avenida Colombo, 5970, Jardim Universitário

Cep 87020-900, Maringá, Paraná, Brasil

Tel.: + 55 (44) 3011-4805

E-mail: leydepeder@yahoo.com.br

\section{Authors information}

DWR - Bachelor in Pharmacy course. University Center FAG. CMS and LDP - Doctor Teacher of Pharmacy course in University Center FAG. HSM - Student of Pharmacy in University Center FAG. VLB - Mester Teacher. Center of Medical and Pharmaceutical Sciences. UNIOESTE. DMI - Mester. Cascavel Municipal Laboratory. JJVT - Doctor Teacher. Post - Graduate Program in Biosciences and Physiopathology. UEM.

\section{Authors contribution}

DWR was responsible for data collection, design and writing of the manuscript. HSM was responsible for correction and translation of the manuscript VLB was responsible for study design. CMS was responsible for revision and correction of the manuscript. DMI was responsible for data collection. JJVT was responsible for final revision and correction of the manuscript. LDP was responsible for study design, data analysis and interpretation. 